Article

\title{
Nitrogen ligands in two-dimensional covalent organic frameworks for metal catalysis
}

\author{
Jianqiang Zhang a, Yongsheng Peng b, Wenguang Leng b,*, Yanan Gao ${ }^{\text {b }}$, Feifei Xu ${ }^{\text {b }}$, Jinling Chai a,\# \\ a College of Chemistry, Chemical Engineering and Material Science, Shandong Normal University, Jinan 250014, Shandong, China \\ ${ }^{\mathrm{b}}$ Dalian Institute of Chemical Physics, Chinese Academy of Sciences, Dalian 116023, Liaoning, China
}

A R T I C L E I N F O

Article history:

Received 9 December 2015

Accepted 18 January 2016

Published 5 April 2016

\section{Keywords:}

Covalent organic framework

Metal catalysis

Heck reaction

Nitrogen ligand

Palladium

\begin{abstract}
A B S T R A C T
We introduced bipyridine ligands into a series of two-dimensional (2D) covalent organic frameworks (COFs) using 2,2'-bipyridine-5,5'-dicarbaldehyde (2,2'-BPyDCA) as a component in the mixed building blocks. The framework of the COFs was formed by the linkage of imine groups. The ligand content in the COFs was synthetically tuned by the content of 2,2'-BPyDCA, and thus the amount of metal, palladium(II) acetate, bonded to the nitrogen ligands could be manipulated. Both the bipyridine ligands and imine groups can coordinate with $\mathrm{Pd}(\mathrm{II})$ ions, but the loading position can be varied, with one ligand favoring binding in the space between adjacent COFs' layers and the other ligand favoring binding within the pores of the COFs. The Pd(II)-loaded COFs exhibited good catalytic activity for the Heck reaction.
\end{abstract}

(C) 2016, Dalian Institute of Chemical Physics, Chinese Academy of Sciences. Published by Elsevier B.V. All rights reserved.

\section{Introduction}

An emerging class of porous materials is covalent organic frameworks (COFs) made up of light weight elements (e.g., B, C, $\mathrm{H}, \mathrm{N}, \mathrm{O})[1-4]$. COFs have been investigated extensively in recent years because of their potential applications in a number of areas, including catalysis [5-9], gas storage/separation [10-14], sensing $[15,16]$ and energy conversion [17-24]. COFs can be synthesized using the general principles of reticular chemistry where organic building blocks with pre-designed geometries and radicals are linked together by the formation of covalent bonds to give an extended periodic network. The general features of this strategy allow for the flexible control of pore parameters (e.g., size, shape, volume, distribution) and also favor the introduction of functional active sites onto the skeleton of the COFs. As a result, COFs, which are also known as "organic zeolites", are widely recognized as promising supports for the immobilization of catalysts for use in organic synthesis.

2D COFs are easier to prepare than their 3D counterparts because of their structural simplicity [25-29], and they have therefore been explored in much greater detail for their application to catalysis [5-8]. Consideration of a typical 2D COF structure reveals that the covalently bonded planar sheets are stacked together by $\pi-\pi$ interactions leading to the formation of eclipsed or staggered columnar arrays [1]. This vertical alignment of COFs leads to the formation of one-dimensional (1D) open channels, which can significantly enhance the diffusion of substances and also be used to support catalysts through the modification of the skeleton of the COFs $[6,30]$. Furthermore, although classical boroxine- and boronate-ester-based COFs are sensitive to moisture [31,32], the more recently developed COFs derived from nitrile trimeriza-

\footnotetext{
* Corresponding author. Tel: +86-411-84379167; E-mail: lengwg@dicp.ac.cn

\# Corresponding author. E-mail: jlchai99@163.com

This work was supported by the National Natural Science Foundation of China (21473196, 21403214), the 100-Talents Program of Chinese Academy of Sciences and State Key Laboratory of Fine Chemicals, Dalian University of Technology (KF1415).

DOI: 10.1016/S1872-2067(15)61050-6 | http://www.sciencedirect.com/science/journal/18722067 | Chin. J. Catal., Vol. 37, No. 4, April 2016
} 
tion [33] and Schiff-base [34-36] reactions exhibit much better stability at high temperatures and in a range of different solvents, making them useable at standard catalytic conditions. In general, 2D imine-type (i.e., Schiff-base) COFs that incorporate $\mathrm{Pd}$ ions or Pd nanoparticles have shown superior catalytic performance in $\mathrm{C}-\mathrm{C}$ coupling reactions than conventional $\mathrm{Pd}$ catalysts $[5,8]$. The strong coordination effect between the imine ligands and noble metal leads to negligible levels of catalyst leaching after repeated catalytic cycles. Furthermore, given that the imine groups can be uniformly distributed throughout the COFs, their one-to-one interaction with the catalyst allows for the isolation of the active sites of the catalyst at a molecular level [37]. This level of uniform dispersion is not easy to achieve with conventional porous supports.

Several reports have been published on the application of 2D imine-linked COFs as catalyst carriers, where the imine groups were used to bind metallic guests $[5,8]$. Given that the density of the imine groups within a certain COF is usually constant, it is challenging to manipulate the amount of catalyst on the surface of the support. With this in mind, it was interesting to introduce different nitrogen ligands into the COFs simultaneously and regulate their contents to allow for controllable metal loading. Bipyridine units have recently been incorporated at the pore edge of metal organic frameworks (MOFs) $[37,38]$ and COFs [30]. The versatile combination of these nitrogen ligands with metallic components is well recognized in coordination chemistry. As a result, bipyridine units can be used as a second type of nitrogen ligand that can be used in conjunction with imine type ligands in the skeleton of the COFs.

Here, we report the development of a novel procedure for the control of the nitrogen content of the ligands in 2D COFs using a pore surface engineering strategy [39]. Imine and bipyridine groups were both included in the skeleton of the COFs to allow for controllable metal loading. These two types of nitrogen ligands can both coordinate palladium(II) acetate $\left(\mathrm{Pd}(\mathrm{OAc})_{2}\right)$, but the loading position of the $\mathrm{Pd}(\mathrm{OAc})_{2}$ can be varied. The imine ligand favors binding $\mathrm{Pd}(\mathrm{OAc})_{2}$ in the space between adjacent layers of the COFs, while the bipyridine ligand would coordinate $\mathrm{Pd}(\mathrm{II})$ in the pores of the COF. The catalytic performances of these COFs were investigated and the results indicated that the $\mathrm{Pd}(\mathrm{II})$-based COF exhibited good catalytic efficiency for the Heck reaction.

\section{Experimental}

\subsection{Materials}

All the reagents were used as received without further purification. 1,3,6,8-tetrabromopyrene, 4-(4,4,5,5-tetramethyl1,3,2-dioxaborolan-2-yl)aniline, 4-formylphenylboronic acid, 4,4'-biphenyl dialdehyde, $\mathrm{Pd}(\mathrm{OAc})_{2}$, and tetrakis(triphenylphosphine) palladium $(0)$ were purchased from TCI Chemicals. 5,5'-dimethyl-2,2'-dipyridyl, tert-butoxy bis(dimethylamino)methane, and benzidine dihydrochloride were purchased from Aldrich. Iodobenzene, 4-iodotoluene, 4-iodoanisole, 4-iodobenzonitrile, and 1,4-diiodobenzene were purchased from Aladdin. Mesitylene, dioxane, acetic acid, di- methylacetamide, tetrahydrofuran, acetone, dichloromethane, methanol, ether, chloroform, $\mathrm{N}, \mathrm{N}$-dimethylformamide, toluene, styrene, hexadecane, hydrochloric acid, fuming nitric acid, potassium carbonate, anhydrous magnesium sulphate and sodium periodate were purchased from Sinopharm Chemical Reagent Co.

\subsection{Synthesis}

Synthesis of the building blocks. 4,4',4",4'"'-(pyrene-1,3,6,8tetrayl) tetraaniline (PyTTA) [30], 2,2'-bipyridine-5,5'-dicarbaldehyde (2,2'-BPyDCA) [40], and 1,3,6,8-tetrakis(4formylphenyl) pyrene (TFPPy) [41] were prepared according to literature reports.

Synthesis of $25 \%$ BPy COF. 2,2'-BPyDCA (16 mg, 0.075 mmol), 4,4'-biphenyl dialdehyde (47 $\mathrm{mg}, 0.225 \mathrm{mmol}$ ) and PyTTA ( $85 \mathrm{mg}, 0.15 \mathrm{mmol}$ ) were placed in a glass ampule vessel $(20 \mathrm{~mL})$, followed by adding a solution of mesitylene/dioxane/3 mol/L acetic acid (3/3/1 by volume; $3.5 \mathrm{~mL})$. The mixture was sonicated for $5 \mathrm{~min}$ and then flash frozen in liquid nitrogen. The vessel was evacuated to a pressure of $\sim 20$ $\mathrm{Pa}$, flame-sealed, and heated at $120{ }^{\circ} \mathrm{C}$ for $3 \mathrm{~d}$. The resulting precipitate was washed sequentially with tetrahydrofuran (3 times) and acetone ( 3 times) to give a powder. This was dried at $120{ }^{\circ} \mathrm{C}$ under vacuum for $12 \mathrm{~h}$ to give the desired product in $88 \%$ yield. Elemental analysis (\%) calcd. for $\left(\mathrm{C}_{67} \mathrm{H}_{41} \mathrm{~N}_{5}\right)_{n}$ : C 87.9; H 4.5; N 7.6; Found: C 82.2; H 4.7; N 6.8.

Synthesis of $50 \%$ BPy COF. This material was synthesized in the same way as the $25 \%$ BPy COF, except for the feed ratio of the two dialdehydes: 2,2'-BPyDCA (31 mg, $0.15 \mathrm{mmol}$ ) and 4,4'-biphenyl dialdehyde ( $31 \mathrm{mg}, 0.15 \mathrm{mmol}$ ). The product was isolated as a powder in $88 \%$ yield. Elemental analysis (\%) calcd. for $\left(\mathrm{C}_{66} \mathrm{H}_{40} \mathrm{~N}_{6}\right)_{n}$ : C 86.5; H 4.4; N 9.1; Found: C 80.9; H 4.5; N 7.8.

Synthesis of 75\% BPy COF. This material was synthesized in the same way as the $25 \%$ BPy COF, except for the feed ratio of the two dialdehydes: 2,2'-BPyDCA (47 mg, $0.225 \mathrm{mmol}$ ) and 4,4'-biphenyl dialdehyde ( $16 \mathrm{mg}, 0.075 \mathrm{mmol}$ ). The product was isolated as a powder in $83 \%$ yield. Elemental analysis (\%) calcd. for $\left(\mathrm{C}_{65} \mathrm{H}_{39} \mathrm{~N}_{7}\right)_{n}$ : C 85.1; $\mathrm{H} 4.2 ; \mathrm{N} 10.7$; Found: $\mathrm{C} 78.7 ; \mathrm{H}$ 4.5; N 9.1.

Synthesis of $100 \%$ BPy COF. This material was synthesized in the same way as the $25 \%$ BPy COF, except for the feed ratio of the two dialdehydes: 2,2'-BPyDCA (64 mg, $0.30 \mathrm{mmol}$ ) and 4,4'-biphenyl dialdehyde (none). The product was isolated as a powder in $76 \%$ yield. Elemental analysis (\%) calcd. for $\left(\mathrm{C}_{64} \mathrm{H}_{38} \mathrm{~N}_{8}\right)_{n}$ : C 83.7; $\mathrm{H} 4.1$; N 12.2; Found: C 74.8; H 4.7; N 10.3.

Synthesis of $\mathrm{Pd}(\mathrm{II}) @ \mathrm{X} \%$ BPy COF. Pd(OAc)2 was incorporated into $X \%$ BPy COFs using a simple solution infiltration method [5,8]. The resulting composites were named Pd(II)@X\% BPy COFs. In a typical procedure, X\% BPy COFs ( $0.03 \mathrm{mmol}$, calculated using the framework repeating unit) was treated with a solution of $\mathrm{Pd}(\mathrm{OAc})_{2}$ in dichloromethane (15 $\mathrm{mL}$ ). The resulting suspension was stirred at room temperature for $12 \mathrm{~h}$. The precipitate was washed with excess dichloromethane to remove any dissociated $\mathrm{Pd}(\mathrm{OAc})_{2}$ and then dried at $120{ }^{\circ} \mathrm{C}$ under vacuum for $12 \mathrm{~h}$ to give Pd(II)@X\% BPy COFs. 
$\mathrm{Pd}(\mathrm{OAc})_{2}$ was added in excess and the exact fed amount was adjusted based on the total nitrogen content of the COFs. $\mathrm{Pd}(\mathrm{OAc}) 2$ was dosed as follows: $28 \mathrm{mg}, 0.12 \mathrm{mmol}(X=25) ; 33$ $\mathrm{mg}, 0.15 \mathrm{mmol}(X=50) ; 39 \mathrm{mg}, 0.17 \mathrm{mmol}(X=75)$; and $44 \mathrm{mg}$, $0.20 \mathrm{mmol}(X=100)$.

\subsection{Procedure for the Heck reaction}

A mixture of aryl iodide (204 mg, $1.0 \mathrm{mmol}$ ), styrene (120 $\mathrm{mg}, 1.1 \mathrm{mmol})$, potassium carbonate $(276 \mathrm{mg}, 2.0 \mathrm{mmol})$ and $N, N$-dimethylformamide $(5 \mathrm{~mL})$ was stirred and purged with N2. Pd(II)@X\% BPy COFs were then added as catalyst (5 mg, containing slightly less than $0.01 \mathrm{mmol}$ of Pd element). The resulting mixture was heated at $105^{\circ} \mathrm{C}$ under reflux for $5 \mathrm{~h}$. The mixture was then cooled to ambient temperature and filtered, and the solid (catalyst and potassium carbonate blend) was washed with dichloromethane $(3 \times 10 \mathrm{~mL})$. The combined filtrates were washed with water $(20 \mathrm{~mL})$. The separated organic phase was concentrated under vacuum at $90{ }^{\circ} \mathrm{C}$ to give a slurry, which was mixed with water $(20 \mathrm{~mL})$ to precipitate the crude product. This powder sediment was filtered and recrystallized from chloroform to give the pure product. Iodobenzene was selected as the substrate for the recyclability tests with Pd(II)@75\% BPy COF as the catalyst. The catalyst was removed by filtration after each cycle together with the $\mathrm{K}_{2} \mathrm{CO}_{3}$, which was removed by washing with water. The catalyst was then dried under vacuum at $120^{\circ} \mathrm{C}$ and reused for another round of catalysis.

\subsection{Characterization}

Elemental analysis was performed by an organic elemental analyzer (vario MACRO cube, Elementar, Germany). Inductively coupled plasma optical emission spectroscopy (ICP-OES) was conducted by ICP-OES 7300DV (PerkinElmer). The sample was firstly calcined at $1000{ }^{\circ} \mathrm{C}$ in air for $12 \mathrm{~h}$ to burn off organic moieties. The residue was dissolved by aqua regia and then diluted by water for ICP-OES testing. Fourier transform infrared (FT-IR) measurements were carried out on a Bruker spectrophotometer (Model TENSOR27) with powder pressed $\mathrm{KBr}$ pellets. Powder X-ray diffraction (PXRD) analysis was carried out on a Rigaku RINT D/Max 2500 powder diffraction system, using a $\mathrm{Cu} K_{\alpha}$ radiation $(\lambda=0.15432 \mathrm{~nm})$. Thermogravimetric analysis (TGA, STA449F3, NETZSCH, Germany) was performed from room temperature to $750{ }^{\circ} \mathrm{C}$ at a heating rate of 10 ${ }^{\circ} \mathrm{C} / \mathrm{min}$ and a $\mathrm{N}_{2}$ flow rate of $20 \mathrm{~mL} / \mathrm{min}$. The nitrogen physisorption experiment was conducted at $-196{ }^{\circ} \mathrm{C}$ on a QUADRASORB SI gas sorption system (Quantachrome Instruments). The sample was degassed at $120{ }^{\circ} \mathrm{C}$ under vacuum before testing. The specific surface areas were calculated by the Brunauer-Emmett-Teller (BET) method. The pore size distribution was evaluated by the nonlocal density function theory (NLDFT) method. The morphology of sample was observed by a transmission electron microscope (TEM, Tecnai G2 F30, FEI Company, operating at $120 \mathrm{kV}$ ). X-ray photoelectron spectroscopy (XPS) was recorded by an ESCALAB 250Xi equipped with Al $K_{\alpha}$ radiation $(1486.6 \mathrm{eV}, 200 \mathrm{~W})$ on a sample powder pressed pellet. Gas chromatography (GC, Agilent 7890A) was used to monitor the conversion in the reaction using hexadecane as an internal standard and dichloromethane as solvent. ${ }^{1} \mathrm{H}$ and ${ }^{13} \mathrm{C}$ nuclear magnetic resonance (NMR) spectra were recorded by a Bruker Advance III $400 \mathrm{MHz}$ NMR spectrometer (Bruker BioSpin Corporation, Fällanden, Switzerland).

\section{Results and discussion}

Two dialdehyde monomers, namely 2,2'-BPyDCA and 4,4'-biphenyl dialdehyde, were chosen as the building blocks to adjust the nitrogen content of the 2D COFs (Scheme 1). These two monomers were blended together in different molar ratios and reacted with PyTTA using a Schiff-base condensation [30]. Four different 2D imine-linked COFs were synthesized and named as $X \%$ BPy COF $(X=25,50,75,100)$, where $X \%$ represented the molar percentage of 2,2'-BPyDCA present in the dialdehyde blend. The density of the imine groups in the 2D COFs was constant, but the number of bipyridine moieties on the wall of the pores was varied by the feed ratio of the 2,2'-BPyDCA monomer.

FT-IR spectra of the four $X \%$ BPy COFs showed a $\mathrm{C}=\mathrm{N}$ stretching vibration at $1622 \mathrm{~cm}^{-1}$ (Fig. 1), which indicated the successful formation of the imine linkage. The PXRD patterns of the $X \%$ BPy COFs revealed that there were negligible difference in the crystalline structure. Diffraction peaks were observed at $2 \theta=3.2^{\circ}, 4.6^{\circ}, 6.4^{\circ}, 9.7^{\circ}, 12.9^{\circ}$ and $23.8^{\circ}$, which were attributed to the (110), (020), (220), (330), (440) and (001) facets, respectively (Fig. 2). The use of lattice modeling and the Pawley refinement process led to an eclipsed AA stacking model that could reproduce the PXRD results in peak position and intensity. These results showed that the $X \%$ BPy COFs belonged to the $\mathrm{P}_{21212}$ space group with the unit cell parameters of $a=4.214$

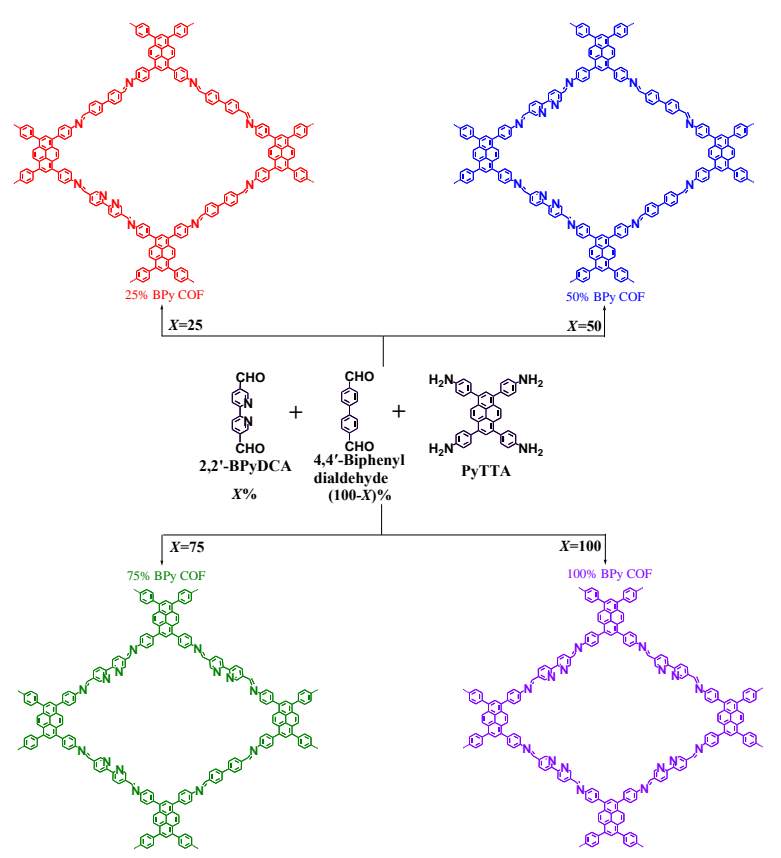

Scheme 1. Pore surface engineering strategy used to modulate the nitrogen content of the 2D imine-type COFs. 


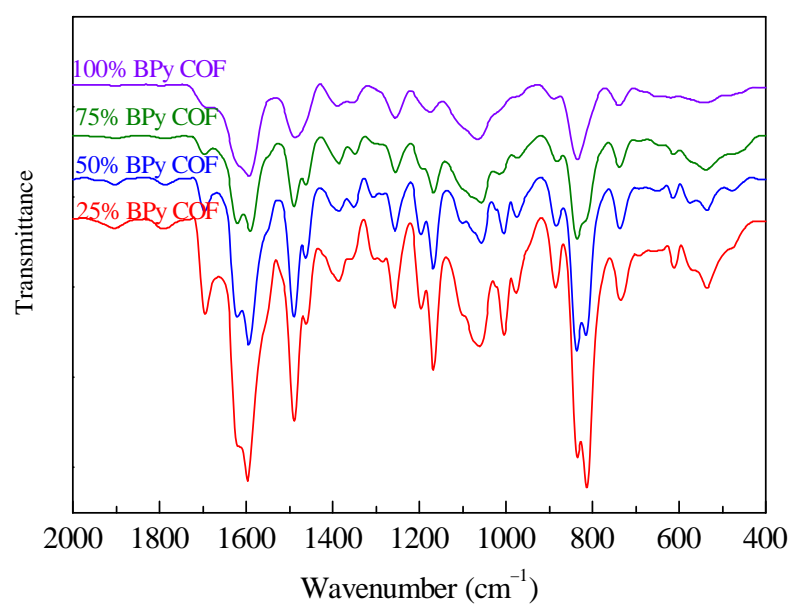

Fig. 1. FTIR spectra of $X \%$ BPy COFs $(X=25,50,75,100)$.

$\mathrm{nm}, b=3.690 \mathrm{~nm}, c=0.374 \mathrm{~nm}$ and $\alpha=\beta=\gamma=90^{\circ}$. These modeling results were in good agreement with the experimental profiles and gave $R_{\mathrm{wp}}$ and $R_{\mathrm{p}}$ values of $6.27 \%$ and $4.74 \%$, respectively. An alternative AB staggered model did not match the observed data. Elemental analysis confirmed that the nitrogen content of the $X \%$ BPy COF was proportional to the feed ratio of 2,2'-BPyDCA, and that it could be tuned in the range of 6.8 wt $\%$ to 10.3 wt $\%$ (Fig. 3). The nominal nitrogen content was higher than the measured value due to residual organic solvent or adsorbed $\mathrm{H}_{2} \mathrm{O}$ in the pores [34]. It is noteworthy that the reaction of only 4,4'-biphenyl dialdehyde with PyTTA under the same conditions did not result in the formation of (a)
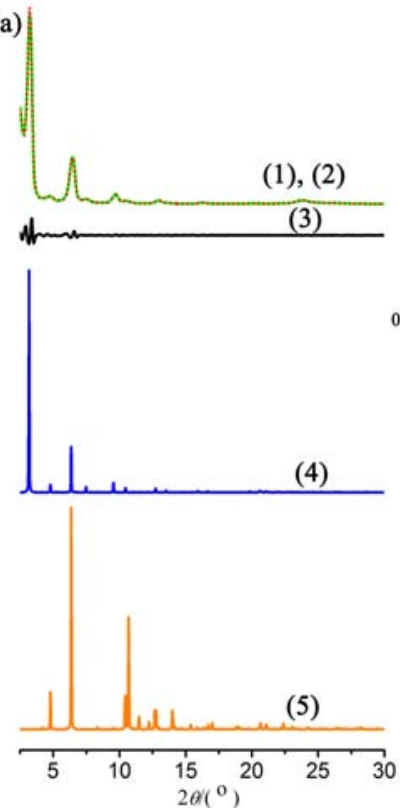

(b)

(c)
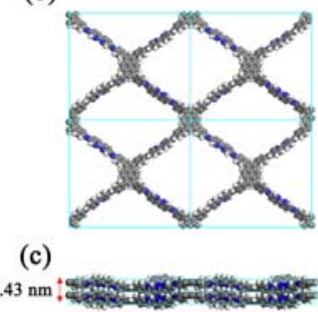

AA stacking

(d)

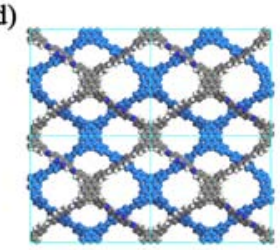

(e)

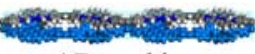

AB stacking

Fig. 2. (a) PXRD patterns of $100 \%$ BPy COF: experimental ((1), red line) Pawley refined $((2)$, green dotted line) difference between experimental and calculated data (3), calculated for AA-stacking (4) and AB-stacking (5); (b) Unit cell structure of 100\% BPy COF using the AA stacking model along the $z$ axis; (c) Unit cell structure of $100 \%$ BPy COF using the AA stacking model along the $y$ axis; (d) Unit cell structure of $100 \%$ BPy COF using the AB stacking model along the $z$ axis; (e) Unit cell structure of $100 \%$ BPy COF using the AB stacking model along the $y$ axis.

well-defined crystalline COFs (named BiPh COFs), which suggested that the addition of 2,2'-BPyDCA was activated and acted in concert with 4,4'-biphenyl dialdehyde during the formation of the COFs to give well-defined crystalline structures [42]. The synthesized $X \%$ BPy COFs were insoluble in water and a range of common organic solvents. TGA curves of the different $X \%$ BPy COFs revealed they were highly stable, with decomposition temperatures of almost $500{ }^{\circ} \mathrm{C}$ (Fig. 4). These results revealed that the COFs would be good catalysts or catalyst carriers for catalytic applications. The porous properties of the COFs were characterized to give the BET surface areas of 538, 1554, 1438 and $1288 \mathrm{~m}^{2} / \mathrm{g}$ for $X$ values of 25, 50, 75 and 100 , respectively, with pore sizes of 2.6 or $2.7 \mathrm{~nm}$. TEM images revealed clear 1D channels with a diameter of $2 \mathrm{~nm}$ (Fig. 5(a)), which provided further demonstration of the formation of well-ordered mesoporous pores.

It was well known that imine and bipyridine units can both coordinate with a variety of noble metals (e.g., Pd, Pt, Rh, Ru and Ir). As a readily available catalyst for organic synthesis, $\mathrm{Pd}(\mathrm{OAc})_{2}$ was selected as the model system to be incorporated into the different $X \%$ BPy COFs using a simple solution infiltration method. The resulting composites are referred to as Pd(II)@X\% BPy COFs. It was envisaged that the formation of a strong interaction between the Pd(II) complex and the nitrogen ligands would lead to the immobilization of $\mathrm{Pd}(\mathrm{OAc})_{2}$ on the COFs. The TEM image revealed that there was very little aggregation of $\mathrm{Pd}(\mathrm{OAc})_{2}$ to block the channels of the COFs (Fig. 5(b)). The thermal stability of the COFs was also well preserved following the loading of the $\mathrm{Pd}(\mathrm{OAc})_{2}$. XPS was performed to

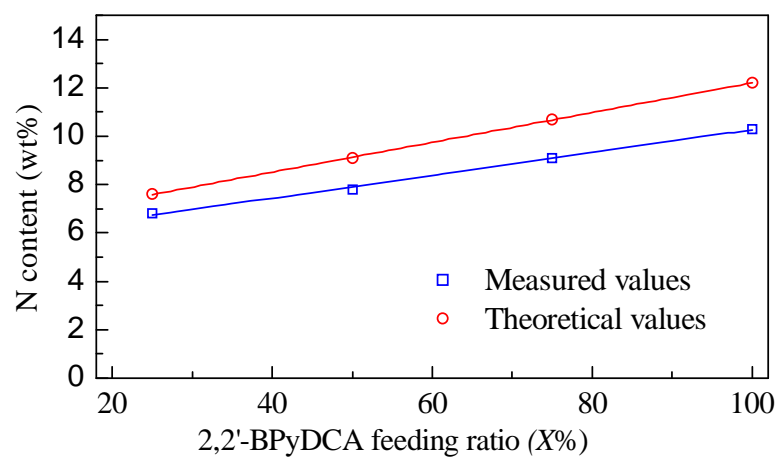

Fig. 3. Elemental analysis of the nitrogen content in the $X \%$ BPy COFs.

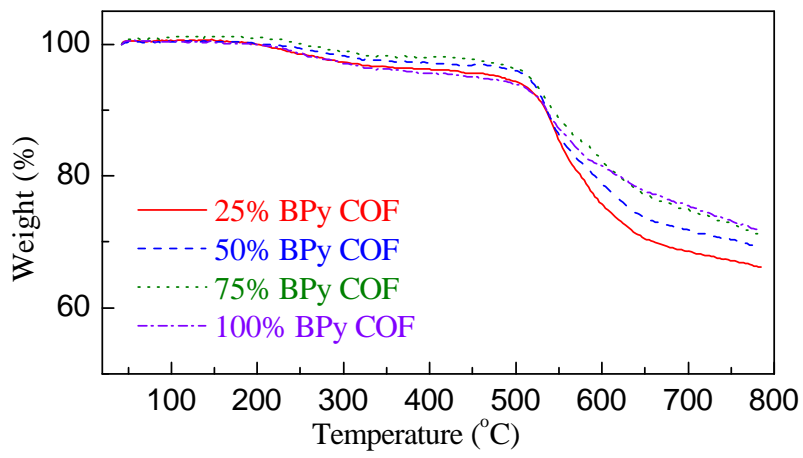

Fig. 4. TGA curves for the $X \%$ BPy COFs. 

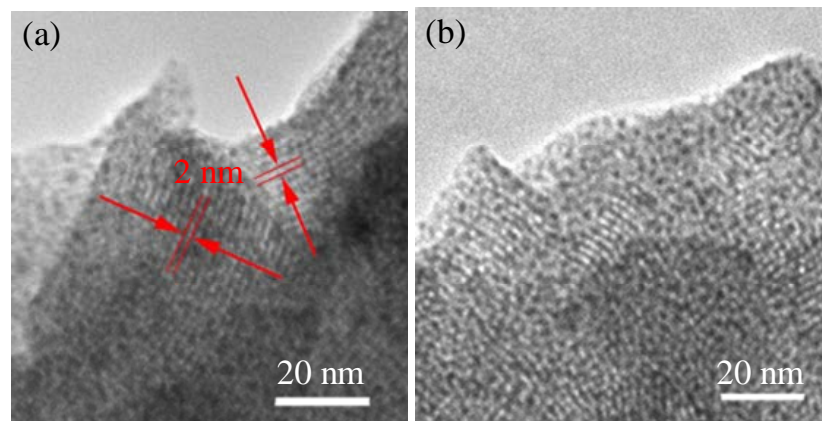

Fig. 5. TEM images of (a) 75\% BPy COF and (b) Pd(II)@75\% BPy COF.

determine the coordinated position of $\mathrm{Pd}(\mathrm{OAc})_{2}$ (Fig. 6). Free $\mathrm{Pd}(\mathrm{OAc})_{2}$ showed a characteristic peak for Pd(II) $3 d_{5 / 2}$ at 338.3 $\mathrm{eV}$. This peak was negatively shifted to $337.9 \mathrm{eV}$ when $\mathrm{Pd}(\mathrm{OAc})_{2}$ was coordinated to a 2,2'-BPyDCA monomer. The bipyridine-free $\mathrm{BiPh}$ COF mentioned above contained only imine groups, and the coordination of these groups to $\mathrm{Pd}(\mathrm{OAc})_{2}$ resulted in a signal at $337.7 \mathrm{eV}$. In contrast, all four of the Pd(II)@X\% BPy COFs gave a Pd(II) $3 d_{5 / 2}$ peak at $337.8 \mathrm{eV}$, which indicated that the bipyridine and imine groups were both involved in the binding of $\mathrm{Pd}(\mathrm{OAc})_{2}$.

The nominal maximum Pd loading was calculated to have a quasi-linear relationship with the total amount of nitrogen ligands (Fig. 7). However, the measured values were lower than these nominal values and did not give a linear relationship with the total nitrogen content of the ligands (Fig. 7). Higher Pd contents were found in Pd(II)@50\% BPy COF (18.2 wt\% Pd element) and Pd(II)@75\% BPy COF (18.7 wt\% Pd element). From consideration of the BET surface areas, it was likely that the structural regularity of the COF scaffolds had an impact on the loading of $\mathrm{Pd}(\mathrm{OAc}) 2$. The insufficient occupation of the nitrogen ligands with $\mathrm{Pd}(\mathrm{OAc})_{2}$ (with a molecular size of $1.06 \times$ $0.5 \times 0.43 \mathrm{~nm}$ [43]) was probably caused by steric limitation since the individual sheets of the 2D COFs were stacked in an eclipsed mode with an interlayer distance of $0.374 \mathrm{~nm}$ (Fig. 2).

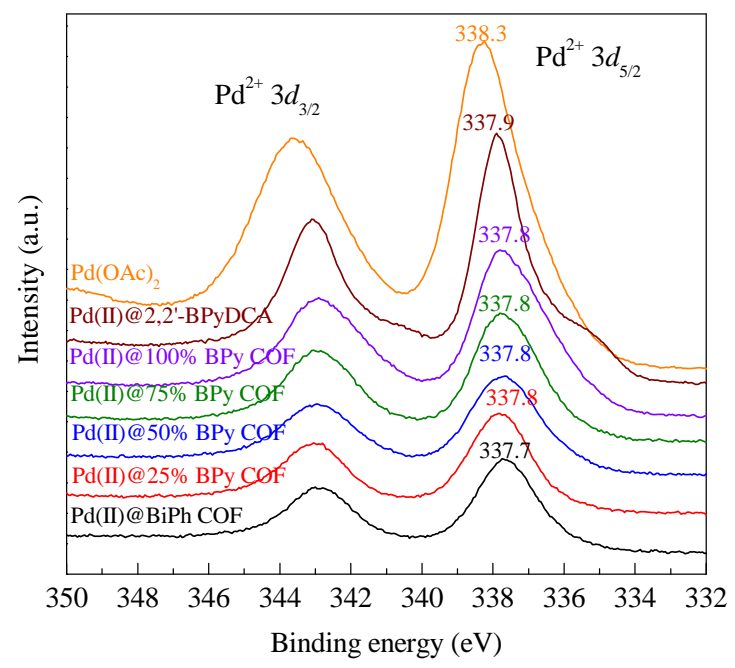

Fig. 6. XPS results $(\mathrm{Pd} 3 d)$ for the samples showing the coordination of $\mathrm{Pd}(\mathrm{OAc})_{2}$. Pure $\mathrm{Pd}(\mathrm{OAc})_{2}$ and the complex formed between $\mathrm{Pd}(\mathrm{OAc})_{2}$ and 2,2'-BPyDCA (Pd(II)@2,2'-BPyDCA) were tested for comparison.

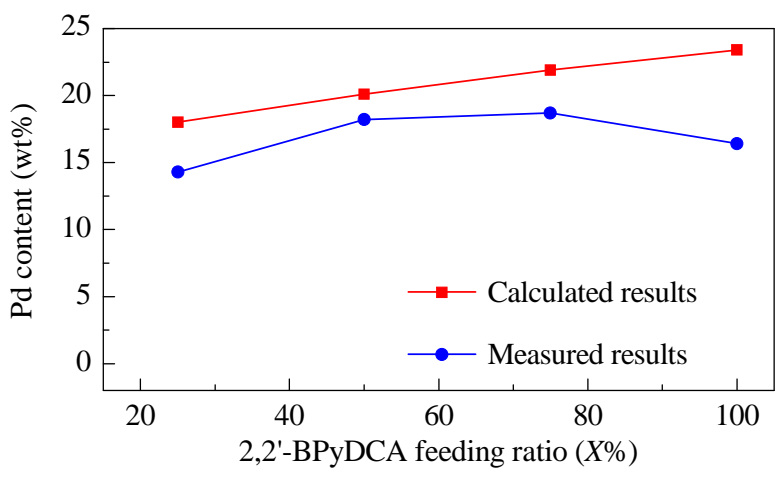

Fig. 7. Nominal and measured Pd loading in the Pd(II)@X\% BPy COFs.

This would have resulted in the balancing of the ligand content and the surface area of the COFs to give the optimum loading. The Pd(II)@X\% BPy COFs gave different Pd loadings in the range of 14.3 to $18.7 \mathrm{wt} \%$, which are among the highest reported values with a similar porous polymer matrix [44]. Although the Pd(II)@X\% BPy COFs still have mesoporous pores, their BET surface areas were decreased significantly to 283, 982, 847 and $731 \mathrm{~m}^{2} / \mathrm{g}$ and the pore diameter of the COFs decreased to 2.3, 2.2, 2.1 and $2.0 \mathrm{~nm}$, respectively, for $X$ values of $25,50,75$ and 100 because of the presence of the guest molecules. To further elucidate the coordination position of the $\mathrm{Pd}(\mathrm{OAc})_{2}$ molecules, another bipyridine-free 2D imine-type COF, named as TF-BD COF, was also synthesized. TF-BD COF can be regarded as the analogue of the BiPh COF as the TF-BD COF has a similar structure to BiPh COF but with much better crystallinity. The TF-BD COF showed negligible change in its pore size both before $(2.6 \mathrm{~nm})$ and after $(2.6 \mathrm{~nm})$ the loading of $\mathrm{Pd}(\mathrm{OAc})_{2}$. This result indicated that the $\mathrm{Pd}(\mathrm{OAc})_{2}$ molecules were coordinated to the imine groups located between adjacent COF sheets, since they did not have an influence on the pore diameter [5]. In contrast, the $\mathrm{Pd}(\mathrm{OAc})_{2}$ molecules coordinated to bipyridine groups occupied the pore space, and therefore led to a reduction in pore size (Fig. 8) [30]. As the percentage of bipyridine units in the COFs increased, their loading ratio with $\mathrm{Pd}(\mathrm{OAc})_{2}$ also increased, which led to the gradual decrease in the pore size.

To characterize the catalytic performance of the COFs, the Pd(II)@X\% BPy COFs were used as heterogeneous catalyst for the classical Heck reaction, which is a powerful and versatile

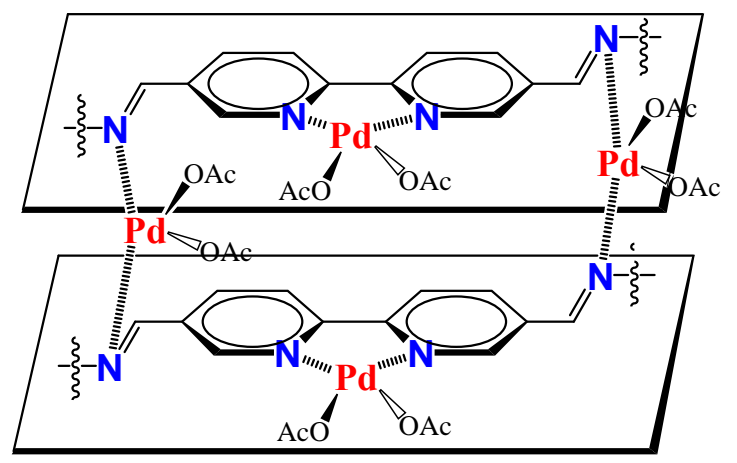

Fig. 8. Scheme for the regulated $\mathrm{Pd}(\mathrm{OAc})_{2}$ coordination on bipyridine and imine groups. 
Table 1

The series of Pd(II)@X\% BPy COFs catalysts for the Heck reaction.

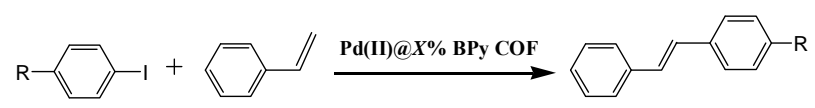

\begin{tabular}{lrccc}
\hline Entry & $X \%$ & $\mathrm{R}$ & Conversion $^{\mathrm{a}}(\%)$ & Yield $^{\mathrm{b}}(\%)$ \\
\hline 1 & 25 & $\mathrm{H}$ & 98 & 92 \\
2 & 50 & $\mathrm{H}$ & 99 & 94 \\
3 & 75 & $\mathrm{H}$ & 99 & 96 \\
4 & 100 & $\mathrm{H}$ & 99 & 95 \\
5 & 25 & $\mathrm{CH}_{3}$ & 98 & 93 \\
6 & 50 & $\mathrm{CH}_{3}$ & 99 & 95 \\
7 & 75 & $\mathrm{CH}_{3}$ & 99 & 96 \\
8 & 100 & $\mathrm{CH}_{3}$ & 99 & 95 \\
9 & 25 & $\mathrm{OCH}_{3}$ & 95 & 90 \\
10 & 50 & $\mathrm{OCH}_{3}$ & 97 & 93 \\
11 & 75 & $\mathrm{OCH}_{3}$ & 97 & 94 \\
12 & 100 & $\mathrm{OCH}_{3}$ & 96 & 91 \\
13 & 25 & $\mathrm{CN}$ & 79 & 73 \\
14 & 50 & $\mathrm{CN}$ & 80 & 77 \\
15 & 75 & $\mathrm{CN}$ & 83 & 80 \\
16 & 100 & $\mathrm{CN}$ & 81 & 76 \\
17 & 25 & $\mathrm{I}$ & 92 & 88 \\
18 & 50 & $\mathrm{I}$ & 94 & 91 \\
19 & 75 & $\mathrm{I}$ & 96 & 92 \\
20 & 100 & $\mathrm{I}$ & 95 & 90 \\
\hline
\end{tabular}

Reaction conditions: aryl iodide $(1.0 \mathrm{mmol})$, styrene $(1.1 \mathrm{mmol})$, potassium carbonate $(2.0 \mathrm{mmol}), \mathrm{Pd}(\mathrm{II}) @ X \%$ BPy COF $(5 \mathrm{mg}$, containing about $0.01 \mathrm{mmol}$ of $\mathrm{Pd}$ ), $\mathrm{N}, \mathrm{N}$-dimethylformamide ( $5 \mathrm{~mL}$ ), $105^{\circ} \mathrm{C}, 5 \mathrm{~h}, \mathrm{~N}_{2}$ protection. A larger charge of styrene $(2.2 \mathrm{mmol})$ was added when 1,4-diiodobenzene containing twice as many functional groups was used as substrate. a Monitored by gas chromatography using hexadecane as an internal standard and dichloromethane as a solvent. ${ }^{b}$ Isolated yield.

method for the synthesis of arylated alkenes. A model reaction between aryl iodide and styrene was selected and carried out under general $\mathrm{C}-\mathrm{C}$ coupling reacting conditions [8,37]. All the Pd(II)@X\% BPy COFs exhibited high catalytic efficiency for the Heck reaction of a variety of different substrates and gave the desired products in high yields. The results of these reactions are summarized in Table 1. Kinetic studies also showed a large

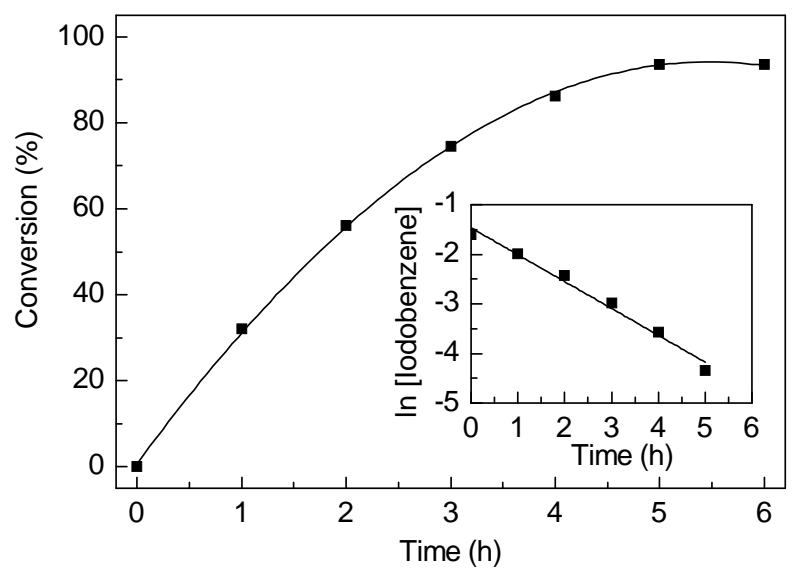

Fig. 9. Reaction kinetics of Pd(II)@75\% BPy COF as catalyst in the Heck reaction. Reacting conditions: iodobenzene $(1.0 \mathrm{mmol})$, styrene (1.1 mmol), potassium carbonate (2.0 mmol), Pd(II)@75\% BPy COF (5 mg, containing slightly less than $0.01 \mathrm{mmol}$ of $\mathrm{Pd}$ element), $\mathrm{N}, \mathrm{N}$-dimethylformamide $(5 \mathrm{~mL}), 105^{\circ} \mathrm{C}, 5 \mathrm{~h}, \mathrm{~N}_{2}$ atmosphere. The conversion was monitored by GC using hexadecane as internal standard. The reaction was completed in $5 \mathrm{~h}$. Inset: plot of log of the remaining iodobenzene concentration versus time which exhibited a first-order rate constant of $k=0.542 \pm 0.034 \mathrm{~h}^{-1}$.

rate constant of $k=0.542 \pm 0.034 \mathrm{~h}^{-1}$ when Pd(II)@75\% BPy COFs was used as catalyst with iodobenzene as the substrate (Fig. 9). The good catalytic properties of the COFs prepared in the current study can be attributed to their higher Pd loadings (14.3-18.7 wt\%) and the larger surface areas of the catalyst carriers (283-982 $\mathrm{m}^{2} / \mathrm{g}$ ) compared to those reported in the literature [44]. The Pd(II)@75\% BPy COF afforded the best catalytic performance of the four candidates tested, and was used further to evaluate its recyclability. Superior catalytic activity was maintained ( $>90 \%$ isolated yield) by this catalyst for up to four cycles (Fig. 10(a)). The crystalline structure of the scaffold of the COF was also found to be well preserved after each cycle (Fig. 10(b)), which highlighted the high stability of this catalyst in the catalytic environment. The heterogeneous nature of the catalyst was also confirmed using a leaching test. In a typical procedure, the supernatant was isolated after 1 cycle of the catalytic experiment and mixed with freshly pre-

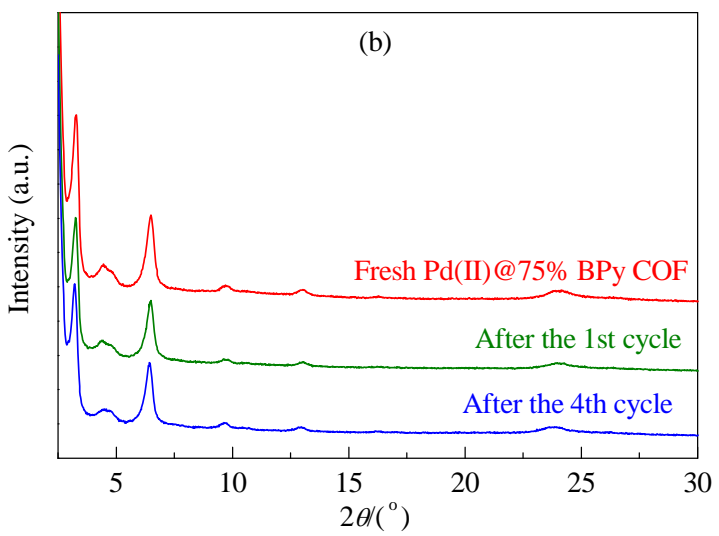

Fig. 10. (a) Recyclability test of the Pd(II)@75\% BPy COF catalyst for the Heck reaction. (b) PXRD patterns of the Pd(II)@75\% BPy COF before and after the recycling test. Iodobenzene was selected as the model substrate for this reaction. All other reaction conditions see Table 1. 
pared substrates for a new round of the reaction. It is found that very little conversion was obtained under these conditions. ICP-OES measurements also confirmed that no Pd element was being lost from the COFs after the reaction. On the basis of these results, it is likely that other reactions can also be catalyzed. These experiments will promote the application of COFs as catalysts.

\section{Conclusions}

We synthesized a series of 2D $X \%$ BPy COFs $(X=25,50,75$, $100)$ containing two different nitrogen ligands (imine and bipyridine groups) as a support for the immobilization of $\mathrm{Pd}(\mathrm{OAc})_{2}$. The total nitrogen content can be tuned from 6.8 to $10.3 \mathrm{wt} \%$ by varying the feed ratio of 2,2 '-BPyDCA. Both bipyridine and imine groups behaved in a similar manner except for the binding location: imine groups favored binding in the space between adjacent COFs layers and bipyridine groups favored binding in the pores of the COFs. The Pd loading was determined by both the ligand content and surface area of the COFs, and could be varied between 14.3 and 18.7 wt\%. Due to the high surface area and high Pd loading, the Pd(II)@X\% BPy COFs exhibited outstanding catalytic efficiency in the Heck reaction. Pd(II)@75\% BPy COF was the best catalyst of the four and its good recyclability and stability were also confirmed. These results offer a unique opportunity for the tuning of the structural parameters of COF-based heterogeneous catalysts.

\section{References}

[1] A. P. Côté, A. I. Benin, N. W. Ockwig, M. O'Keeffe, A. J. Matzger, O. M. Yaghi, Science, 2005, 310, 1166-1170.

[2] H. M. El-Kaderi, J. R. Hunt, J. L. Mendoza-Cortés, A. P. Côté, R. E. Taylor, M. O'Keeffe, O. M. Yaghi, Science, 2007, 316, 268-272.

[3] X. Feng, X. S. Ding, D. L. Jiang, Chem. Soc. Rev., 2012, 41 6010-6022.
[4] S. Y. Ding, W. Wang, Chem. Soc. Rev., 2013, 42, 548-568.

[5] S. Y. Ding, J. Gao, Q. Wang, Y. Zhang, W. G. Song, C. Y. Su, W. Wang, J. Am. Chem. Soc., 2011, 133, 19816-19822.

[6] H. Xu, X. Chen, J. Gao, J. B. Lin, M. Addicoat, S. Irle, D. L. Jiang, Chem. Commun., 2014, 50, 1292-1294.

[7] P. Pachfule, S. Kandambeth, D. D. Díaz, R. Banerjee, Chem. Commun., 2014, 50, 3169-3172.

[8] P. Pachfule, M. K. Panda, S. Kandambeth, S. M. Shivaprasad, D. D. Díaz, R. Banerjee, J. Mater. Chem. A, 2014, 2, 7944-7952.

[9] Q. R. Fang, S. Gu, J. Zheng, Z. B. Zhuang, S. L. Qiu, Y. S. Yan, Angew. Chem. Int. Ed., 2014, 53, 2878-2882.

[10] S. S. Han, H. Furukawa, O. M. Yaghi, W. A. Goddard III, J. Am. Chem. Soc., 2008, 130, 11580-11581.

[11] H. Furukawa, O. M. Yaghi, J. Am. Chem. Soc., 2009, 131, 8875-8883.

[12] C. J. Doonan, D. J. Tranchemontagne, T. G. Glover, J. R. Hunt, O. M. Yaghi, Nat. Chem., 2010, 2, 235-238.

[13] H. P. Ma, H. Ren, S. Meng, Z. J. Yan, H. Y. Zhao, F. X. Sun, G. S. Zhu, Chem. Commun., 2013, 49, 9773-9775.

[14] M. G. Rabbani, A. K. Sekizkardes, Z. Kahveci, T. E. Reich, R. S. Ding, H. M. El-Kaderi, Chem. Eur. J., 2013, 19, 3324-3328.

[15] S. Dalapati, S. B. Jin, J. Gao, Y. H. Xu, A. Nagai, D. L. Jiang, J. Am. Chem. Soc., 2013, 135, 17310-17313.

[16] J. Zhang, L. B. Wang, N. Li, J. F. Liu, W. Zhang, Z. B. Zhang, N. C. Zhou, X. L. Zhu, CrystEngComm, 2014, 16, 6547-6551.

[17] S. Wan, J. Guo, J. Kim, H. Ihee, D. L. Jiang, Angew. Chem. Int. Ed., 2008, 47, 8826-8830

[18] S. Wan, J. Guo, J. Kim, H. Ihee, D. L. Jiang, Angew. Chem. Int. Ed., 2009, 48, 5439-5442.

[19] X. Feng, L. Chen, Y. Honsho, O. Saengsawang, L. L. Liu, L. Wang, A. Saeki, S. Irle, S. Seki, Y. P. Dong, D. L. Jiang, Adv. Mater., 2012, 24, 3026-3031.

[20] E. L. Spitler, J. W. Colson, F. J. Uribe-Romo, A. R. Woll, M. R. Giovino, A. Saldivar, W. R. Dichtel, Angew. Chem. Int. Ed., 2012, 51, 2623-2627.

[21] M. Dogru, M. Handloser, F. Auras, T. Kunz, D. Medina, A. Hartschuh, P. Knochel, T. Bein, Angew. Chem. Int. Ed., 2013, 52, 2920-2924.

[22] L. Chen, K. Furukawa, J. Gao, A. Nagai, T. Nakamura, Y. P. Dong, D. L. Jiang, J. Am. Chem. Soc., 2014, 136, 9806-9809.

\section{Graphical Abstract}

Chin. J. Catal., 2016, 37: 468-475 doi: 10.1016/S1872-2067(15)61050-6

\section{Nitrogen ligands in two-dimensional covalent organic frameworks for metal catalysis}

Jianqiang Zhang, Yongsheng Peng, Wenguang Leng *, Yanan Gao, Feifei Xu, Jinling Chai* Shandong Normal University; Dalian Institute of Chemical Physics, Chinese Academy of Sciences

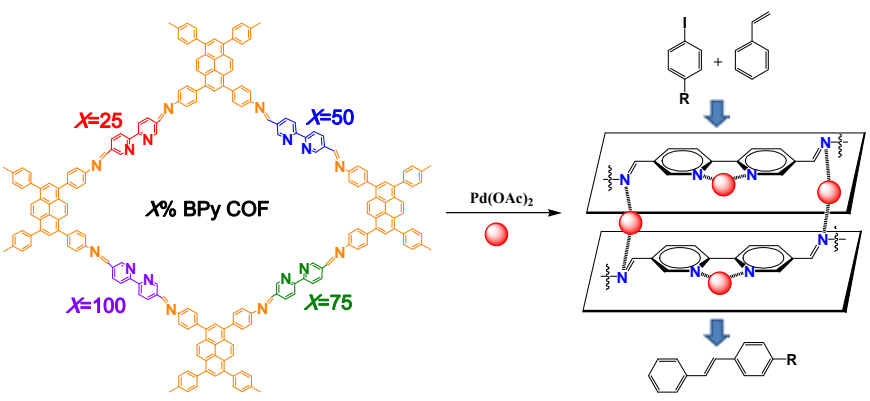

Bipyridine ligands and imine groups were both introduced into two-dimensional covalent organic frameworks (COFs) to dock with palladium(II) acetate and the metal loaded COFs exhibited good catalytic performance towards Heck reaction. 
[23] C. R. DeBlase, K. E. Silberstein, T. T. Truong, H. D. Abruña, W. R. Dichtel, J. Am. Chem. Soc., 2013, 135, 16821-16824.

[24] L. Stegbauer, K. Schwinghammer, B. V. Lotsch, Chem. Sci., 2014, 5, 2789-2793.

[25] N. L. Campbell, R. Clowes, L. K. Ritchie, A. I. Cooper, Chem. Mater., 2009, 21, 204-206.

[26] B. P. Biswal, S. Chandra, S. Kandambeth, B. Lukose, T. Heine, R. Banerjee, J. Am. Chem. Soc., 2013, 135, 5328-5331.

[27] J. W. Colson, A. R. Woll, A. Mukherjee, M. P. Levendorf, E. L. Spitler, V. B. Shields, M. G. Spencer, J. Park, W. R. Dichtel, Science, 2011, $332,228-231$.

[28] X. H. Liu, C. Z. Guan, S. Y. Ding, W. Wang, H. J. Yan, D. Wang, L. J. Wan, J. Am. Chem. Soc., 2013, 135, 10470-10474.

[29] N. A. A. Zwaneveld, R. Pawlak, M. Abel, D. Catalin, D. Gigmes, D. Bertin, L. Porte, J. Am. Chem. Soc., 2008, 130, 6678-6679.

[30] X. Chen, N. Huang, J. Gao, H. Xu, F. Xu, D. L. Jiang, Chem. Commun., 2014, 50, 6161-6163.

[31] A. P. Côté, H. M. El-Kaderi, H. Furukawa, J. R. Hunt, O. M. Yaghi, J. Am. Chem. Soc., 2007, 129, 12914-12915.

[32] L. M. Lanni, R. W. Tilford, M. Bharathy, J. J. Lavigne, J. Am. Chem. Soc., 2011, 133, 13975-13983.

[33] P. Kuhn, M. Antonietti, A. Thomas, Angew. Chem. Int. Ed., 2008, 47,
3450-3453.

[34] F. J. Uribe-Romo, J. R. Hunt, H. Furukawa, C. Klöck, M. O'Keeffe, 0. M. Yaghi, J. Am. Chem. Soc., 2009, 131, 4570-4571.

[35] F. J. Uribe-Romo, C. J. Doonan, H. Furukawa, K. Oisaki, O. M. Yaghi, J. Am. Chem. Soc., 2011, 133, 11478-11481.

[36] S. Kandambeth, A. Mallick, B. Lukose, M. V. Mane, T. Heine, R. Banerjee, J. Am. Chem. Soc., 2012, 134, 19524-19527.

[37] L. Y. Chen, S. Rangan, J. Li, H. F. Jiang, Y. W. Li, Green Chem., 2014, 16, 3978-3985.

[38] E. D. Bloch, D. Britt, C. Lee, C. J. Doonan, F. J. Uribe-Romo, H. Furukawa, J. R. Long, O. M. Yaghi, J. Am. Chem. Soc., 2010, 132, 14382-14384.

[39] A. Nagai, Z. Q. Guo, X. Feng, S. B. Jin, X. Chen, X. S. Ding, D. L. Jiang, Nat. Commun., 2011, 2, 536.

[40] J. Hodačová, M. Buděšínský, Org. Lett., 2007, 9, 5641-5643.

[41] M. G. Rabbani, A. K. Sekizkardes, O. M. El-Kadri, B. R. Kaafarani, H. M. El-Kaderi, J. Mater. Chem., 2012, 22, 25409-25417.

[42] X. Chen, M. Addicoat, S. Irle, A. Nagai, D. L. Jiang, J. Am. Chem. Soc., 2013, 135, 546-549.

[43] The molecular size was determined by Material Studio Geometry Optimization.

[44] N. Huang, Y. H. Xu, D. L. Jiang, Sci. Rep., 2014, 4, 7228.

\title{
二维共价有机框架材料中引入含氮配体用于络合金属催化
}

\author{
张健强 ${ }^{\mathrm{a}}$, 彭永胜 ${ }^{\mathrm{b}}$, 冷文光 ${ }^{\mathrm{b},}{ }^{*}$, 高艳安 ${ }^{\mathrm{b}}$, 徐斐斐 ${ }^{\mathrm{b}}$, 柴金岭, ${ }^{\mathrm{a}}$, \\ a山东师范大学化学化工与材料科学学院, 山东济南 250014 \\ b 中国科学院大连化学物理研究所, 辽宁大连 116023
}

摘要: 共价有机骨架材料(COF)也被称为 “有机分子篮”, 具有孔道结构开放有序、易于进行化学修饰改性、化学/热稳定性 好等优点, 是一种新型的有机聚合物多孔材料. 近年来, 以COF材料为催化剂载体负载金属化合物用于制备多相反应催化 剂已经成为材料领域研究的热点, 表现出高活性和高选择性. 但是到目前为止, 仍未找到简单有效地控制骨架中金属负载 量和分散性的方法, 这已成为该领域一个具有挑战性的课题.

本文以 2,2'-联吡啶-5,5'一甲醛作为其中一个结构基元, 成功把联吡啶配体引入到二维材料中. 除此之外, 由于COF是 以亚胺键联接构筑形成的, 因此框架中同时存在联吡啶和亚胺键两种含氮配体. 我们通过红外光谱、结构模拟、元素分析、 热失重分析、透射电镜(TEM)、X-射线光电子能谱、电感耦合等离子体色谱等手段详细表征了所制备的二维共价有机框 架材料对醋酸钯 $\left(\mathrm{Pd}(\mathrm{OAc})_{2}\right)$ 分子的络合负载行为.

研究发现, 联吡啶和亚胺键均可参与配位 $\mathrm{Pd}(\mathrm{OAc})_{2}$, 与亚胺键配位的 $\mathrm{Pd}(\mathrm{OAc})_{2}$ 分布于框架的层与层之间, 而与联吡啶配 位的则部分占据了框架的孔道, 导致孔径减小. 另外, 由于框架中的联吡啶配体含量可通过加入 2,2'-联吡啶-5,5'-二甲醛含 量的变化实现线性调控, 因此也可调节与其配位的Pd(OAc) 2 含量, 其负载量可控制在 $14.3-18.7 \mathrm{wt} \%$, 是目前已报道的二维 COF中的最高值; 另外, COF材料中调控金属负载量尚未见报道. TEM结果显示, 负载在框架中的催化剂分子没有发生团 聚, 框架的孔道仍处于开放状态, 因而反应底物可以自由地出入一维孔道并与络合的催化剂充分接触. 另外, 由于催化剂 在框架内部可以达到分子级别的分散, 而且其负载量和负载位置都易于控制, 因而对有机反应表现出了优异的催化性能.

我们尝试了以不同Pd负载量的COF为多相催化剂催化Heck反应. 结果发现, Pd(II)@75\% BPy COF(Pd负载量为最高值 $18.7 \mathrm{wt} \%$ )的催化活性最高, 对不同底物均表现出优异的催化性能, 产率达73-96\%, 反应速率遵循一级动力学曲线. 且催化 剂经多次循环利用仍能保持高活性, 框架的有序结构也未被破坏, 因此该材料有望用于各种类型优异的多相反应催化剂.

关键词: 共价有机框架; 金属催化剂; Heck反应; 含氮配体; 钯

收稿日期: 2015-12-09. 接受日期: 2016-01-18. 出版日期: 2016-04-05.

*通讯联系人. 电话: (0411)84379167; 电子信箱: lengwg@dicp.ac.cn

\#通讯联系人. 电子信箱: jlchai99@163.com

基金来源：国家自然科学基金(21473196, 21403214); 中国科学院百人计划; 大连理工大学精细化工国家重点实验室(KF1415).

本文的英文电子版由Elsevier出版社在ScienceDirect上出版(http://www.sciencedirect.com/science/journal/18722067). 